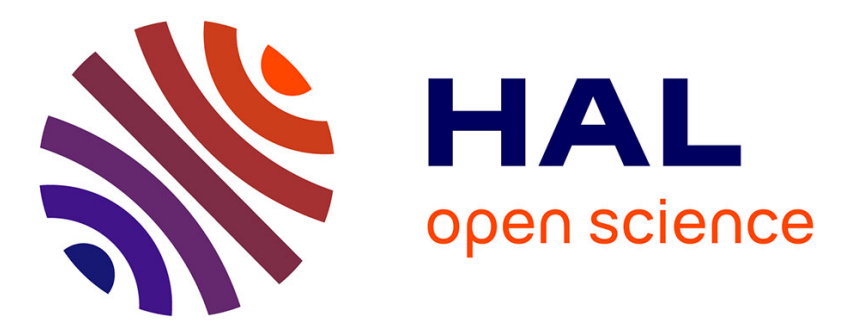

\title{
An instrumented station for the survey of ozone and climate change in the southern tropics
}

Jean-Luc Baray, Jean Leveau, Serge Baldy, Jean Jouzel, Philippe Keckhut, Gilles Bergametti, Gérard Ancellet, Hassan Bencherif, Bertrand Cadet, M. Carleer, et al.

\section{To cite this version:}

Jean-Luc Baray, Jean Leveau, Serge Baldy, Jean Jouzel, Philippe Keckhut, et al.. An instrumented station for the survey of ozone and climate change in the southern tropics. Journal of Environmental Monitoring, 2006, 8 (10), pp.1020-1028. 10.1039/b607762e . hal-00145015

\section{HAL Id: hal-00145015 https://hal.science/hal-00145015}

Submitted on 25 Oct 2016

HAL is a multi-disciplinary open access archive for the deposit and dissemination of scientific research documents, whether they are published or not. The documents may come from teaching and research institutions in France or abroad, or from public or private research centers.
L'archive ouverte pluridisciplinaire HAL, est destinée au dépôt et à la diffusion de documents scientifiques de niveau recherche, publiés ou non, émanant des établissements d'enseignement et de recherche français ou étrangers, des laboratoires publics ou privés. 


\title{
An instrumented station for the survey of ozone and climate change in the southern tropics $\dagger$
}

\author{
J.-L. Baray, ${ }^{* a b}$ J. Leveau ${ }^{b}$ S. Baldy, ${ }^{b}$ J. Jouzel, ${ }^{a}$ P. Keckhut, ${ }^{a c}$ G. Bergametti, ${ }^{d}$ \\ G. Ancellet, ${ }^{e}$ H. Bencherif, ${ }^{b}$ B. Cadet,${ }^{b c}$ M. Carleer, ${ }^{f}$ C. David, ${ }^{a e}$ M. De Mazière, ${ }^{g}$ \\ D. Faduilhe, ${ }^{b}$ S. Godin Beekmann, ${ }^{a e}$ P. Goloub, ${ }^{h}$ F. Goutail, ${ }^{a c}$ J. M. Metzger, ${ }^{b}$ \\ B. Morel, ${ }^{b}$ J. P. Pommereau, ${ }^{c}$ J. Porteneuve, ${ }^{c}$ T. Portafaix,${ }^{b}$ F. Posny ${ }^{b}$ \\ L. Robert ${ }^{b}$ and M. Van Roozendae ${ }^{g}$
}

The assessment of changes induced by human activities on Earth atmospheric composition and thus on global climate requires a long-term and regular survey of the stratospheric and tropospheric atmospheric layers. The objective of this paper is to describe the atmospheric observations performed continuously at Reunion Island $\left(55.5^{\circ}\right.$ east, $20.8^{\circ}$ south) for 15 years. The various instruments contributing to the systematic observations are described as well as the measured parameters, the accuracy and the database. The LiDAR systems give profiles of temperature, aerosols and ozone in the troposphere and stratosphere, probes give profiles of temperature, ozone and relative humidity, radiometers and spectrometers give stratospheric and tropospheric integrated columns of a variety of atmospheric trace gases. Data are included in international networks, and used for satellite validation. Moreover, some scientific activities for which this station offers exceptional opportunities are highlighted, especially air mass exchanges nearby dynamical barriers: (1) On the vertical scale through the tropical tropopause layer (stratosphere-troposphere exchange). (2) On the quasi-horizontal scale across the southern subtropical barrier separating the tropical stratospheric reservoir from mid- and high latitudes.

\section{Introduction}

In the last 25 years, research in atmospheric chemistry and physics has been marked by the destruction of the stratospheric ozone layer in Antarctica ${ }^{1}$ and the impact of increasing levels of carbon dioxide and other greenhouse gases on global climate. ${ }^{2,3}$ The discovery of the sensitivity of the global atmosphere to growing emissions of anthropogenic substances put

\footnotetext{
${ }^{a}$ Pierre-Simon Laplace (IPSL), Université Versailles Saint Quentin,

5 Boulevard d'Alembert, 78280 Guyancourt, France

${ }^{b}$ Laboratoire de L'Atmosphère et des Cyclones (LACy), UMRCNRS 8105, 15, av. René Cassin, BP 7151, 97715 St-Denis Cedex

9, La Réunion, France. E-mail: baray@univ-reunion.fr; Fax: 26293

86 65; Tel: 262938664

${ }^{c}$ Service d'Aéronomie (SA), UMR-CNRS 7620 Verrières le Buisson, 91371, France

${ }^{d}$ Laboratoire Inter-Universitaire des Systèmes Atmosphériques (LISA), UMR-CNRS 7583, 61 avenue du Général de Gaulle, F-94010 Créteil, France

e Service d'Aéronomie (SA), UMR-CNRS 7620 Université Pierre et

Marie Curie, 4 place Jussieu, 75252 Paris Cédex 05, France

${ }^{f}$ Université Libre de Bruxelles (ULB), Chimie Quantique et

Photophysique, CP 160/09, Avenue F.D. Roosevelt 50, 1050

Bruxelles, Belgium

${ }^{g}$ Institut d'Aéronomie Spatiale de Belgique (IASB-BIRA), 3 Av. Circulaire, B-1180 Bruxelles, Belgium

${ }^{h}$ Laboratoire d'Optique Atmospherique (LOA), Université des sciences et technologies Lille 1, UMR-CNRS 8518, 59655

Villemenuve d'asq, France
}

in evidence the lack of adequate observations for understanding and thus possibly predicting the global evolution of the composition of the atmosphere (Fig. 1). The NDSC (Network for Detection of Stratospheric Change) was set up rapidly at the end of the eighties based on the use of the most recent research instruments which could be deployed at stations distributed in latitude for starting the mandatory long term monitoring of the composition of the stratosphere. ${ }^{4}$ Largely based on already existing stations at mid- and high latitudes of the Northern Hemisphere, the challenge was to extend the network to other latitudes, particularly to the Southern Hemisphere and the tropics where almost nothing was available. In 2006, to better reflect the free tropospheric and stratospheric coverage of NDSC, measurement, analyses, and modeling activities, as well as to convey the linkage to climate change, the steering committee voted to change the name of the network to NDACC (Network for the Detection of Atmospheric Composition Change). It is indeed now well-known that the UTLS (Upper Troposphere-Lower Stratosphere) is the atmospheric layer where the effects of the climate changes should be particularly marked. For example, climate models predict a cooling in the stratosphere up to $7 \mathrm{~K}$, and a warming in the troposphere of about $2 \mathrm{~K}^{5}{ }^{5}$ Thus, it is of primary importance to be able to detect and quantify such changes and to connect these changes into the different atmospheric compartments, to identify the dynamical links and the strength of their exchanges. 


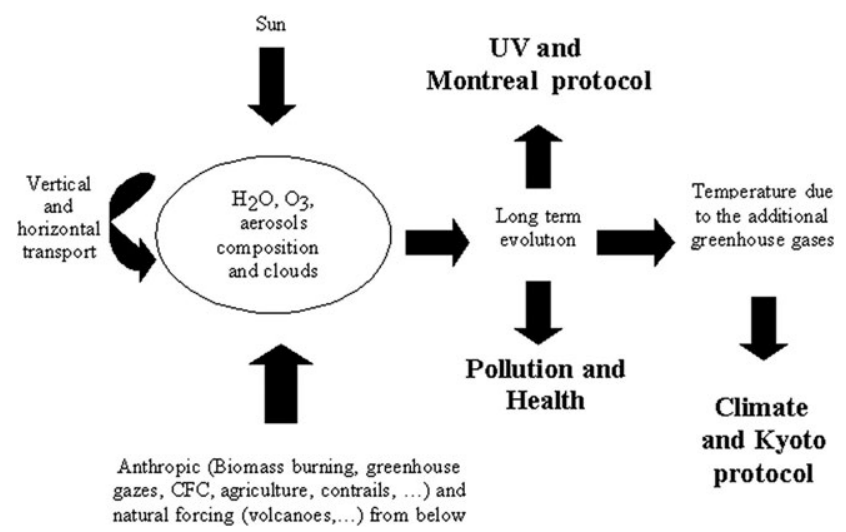

Fig. 1 The primary objective of the NDSC, the survey of the stratosphere, is complementary to the other scientific environmental issues, like pollution, climate change, or atmospheric ozone balance.

Especially, tropical latitude bands are of special interest since, in these regions, the upper troposphere is affected by specific dynamical processes like the subtropical jet stream and the tropical convection. A program like SHADOZ (Southern Hemisphere ADditional OZonesondes) focuses on the tropospheric ozone balance in these regions. ${ }^{6}$ In the stratosphere, tropical waves, meridional transfers of air masses and tidal perturbations of the middle atmosphere are the main drivers of the dynamics. Reunion Island is a tropical island located in the south-western part of the Indian Ocean at $20.8^{\circ} \mathrm{S}$ and $55.5^{\circ} \mathrm{E}$. Due to its location, Reunion Island is seasonally submitted to biomass burning plumes transported from the subcontinent of Southern Africa, which can significantly affect the free tropospheric concentrations of ozone and other pollutants like CO. Moreover, it is affected by the dynamical influence of the subtropical jet stream and the tropical convection. In the stratosphere, the island is located near the subtropical barrier and special patterns of stratospheric ozone transport can be observed.

The understanding of the barrier effect and dynamical exchanges between the tropical reservoir and midlatitudes, and vertically between the troposphere and the stratosphere is of great interest to document climate change and Reunion Island is ideally located to make measurements in order to document these themes (Fig. 2). Hence, in response to the request of the network NDACC, the Service d'Aéronomie and the University of Reunion Island decided in 1991 to start building a stratospheric observing capacity in the southern tropics in the Indian Ocean.

The paper is organized as follow: firstly an overview of the instruments and facilities currently available at Reunion Island is presented. Then some important scientific results already achieved based on these measurements are given, and finally the plans for further improving and developing the station are displayed.

\section{Instrumentation}

The instrumentation operating presently at Reunion Island has been developed gradually. In collaboration with the Service d'Aéronomie (SA/CNRS) and the Institut Pierre

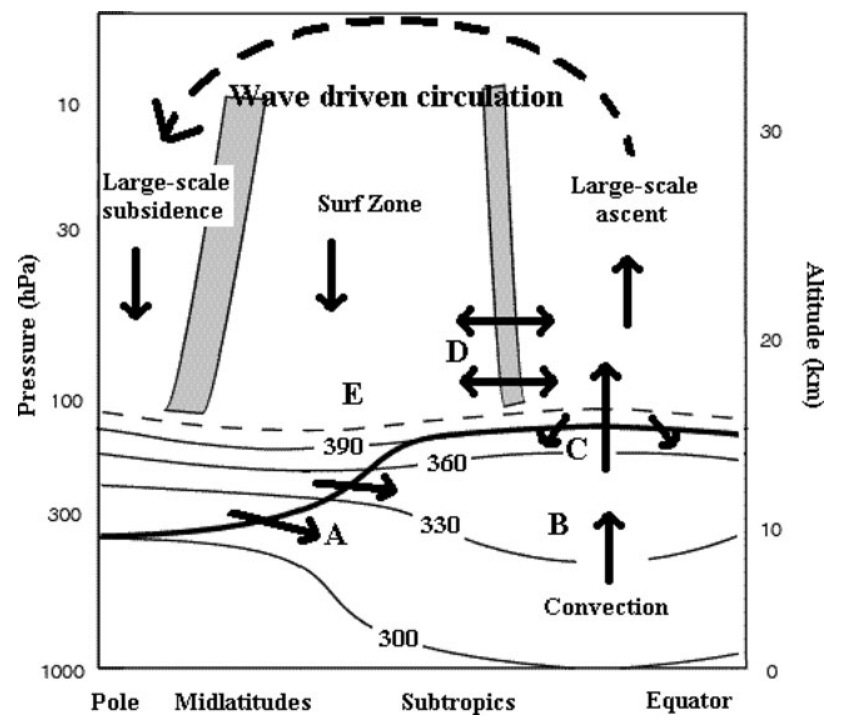

Fig. 2 Latitude-altitude cross-section schematic representation showing the different compartments of the atmosphere. The letters represent the mechanisms studied in Section 3. A: Tropopause folds, cut-off lows, Rossby wave breaking and filamentation of the tropopause induced by the subtropical jet stream. B: Mesoscale modeling of the tropical convection (cyclone, convective depressions), gravity waves induced by the convection. C: Stratosphere-troposphere induced by convection, variability of ozone and water vapor in the tropical UTLS region. D: Stratospheric ozone lamina, meridian exchanges, gravity and Kelvin waves in the tropical stratosphere. As function of the season, Reunion Island can be affected by these mechanisms.

Simon Laplace (IPSL), measurements of ozone, temperature and humidity profiles by radio soundings started in 1992 (Fig. 3). A SAOZ UV-visible spectrometer was installed nearly one year later, in 1993 (SAOZ, Système d'Analyse par Observation Zénitale). Based on the Rayleigh-Mie techniques to retrieve temperature and aerosol profiles, the first LiDAR (Light Detection And Ranging) experiments started by early 1994, thanks to the established expertise of the SA/CNRS at the Observatoire de Haute Provence and Dumont D'Urville. Then, in parallel to the continuous improvement of the existing instruments, several other instruments have been developed and implemented at Reunion station, as a set of complementary instruments, in order to: (1) provide high quality datasets that meet the NDACC quality standard, (2) contribute to validation of a number of global atmospheric experiments on space shuttles or satellites (e.g., TOMS, GOME, ENVISAT, AURA and CALIPSO), (3) survey and report on original geophysical events, such as sudden stratospheric warming, total ozone reduction, biomass burning and stratosphere-troposphere exchanges, (4) improve and assess models outputs at various scales.

In the light of these developments and requirements, the Observatoire de Physique de l'Atmosphère de la Réunion (OPAR) was officially formed in February 2003. It is a French consortium based on four partners: (1) University of Reunion Island, (2) University of Versailles-Saint-Quentin, (3) Reunion Regional Council (Conseil Régional de La Réunion), and (4) CNRS, the French national research centre. 


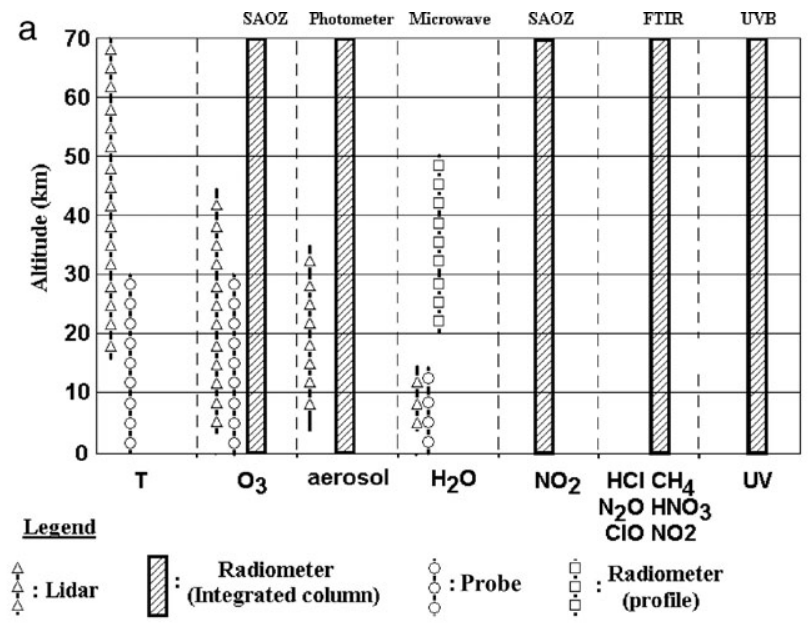

B

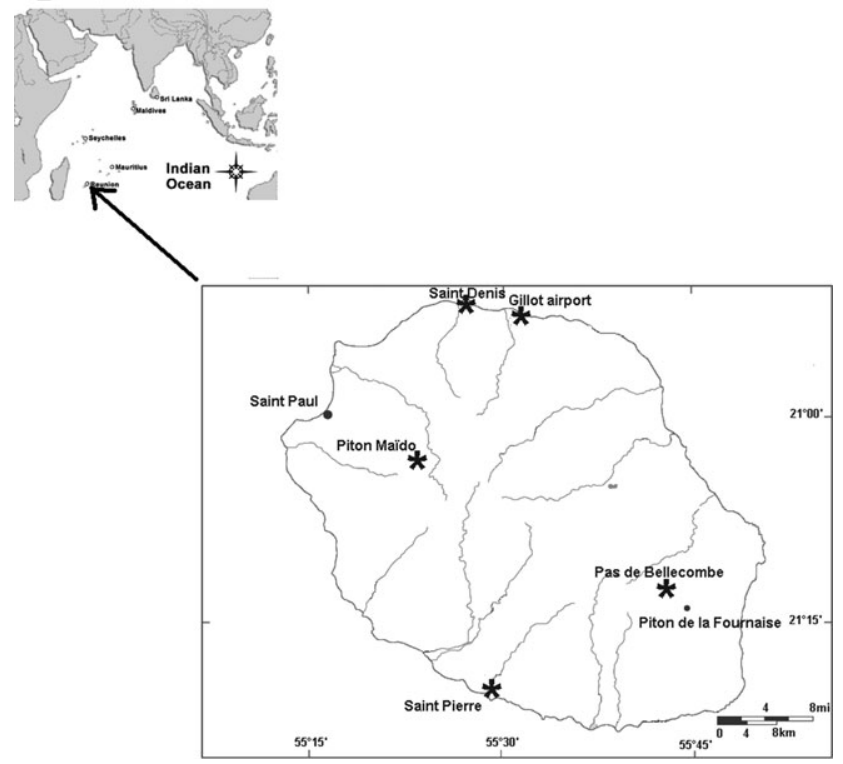

Fig. 3 (a) Parameters (bottom $x$ axis) measured by the instrumental set (top of $x$ axis) developed at Reunion Island, or at the planning stage. (b) Map showing the locations of the instruments on Reunion Island: The university is located at Saint Denis, radio soundings are performed from Gillot airport, and the future altitude station will be located at Piton Maïdo.

The description of the instruments is organized as follow: ozone and water vapor probes, and SAOZ and MAXDOAS UV-visible spectrometers, sun-photometer, FTIR, and finally LiDAR systems. The pictures of each instrument are given in Fig. 4. In order to show how routinely each instrument operates, the annual frequency of measurements is given in Table 1.

\section{Ozone probes}

The ozone probe program started in 1992 using ECC (ElectroChemical Cells) and Vaisala RS80 radio probes providing temperature, pressure and humidity every $7 \mathrm{~s}$ during the ascent of the balloon at $5 \mathrm{~m} \mathrm{~s}^{-1}$ up to the burst altitude at $30-35 \mathrm{~km}$. In 2006, the interface change led to a measurement rate of $2 \mathrm{~s}$ which had improved the resolution, which is about $50 \mathrm{~m}$. The precision of the ozone concentration is estimated to $5 \%$ in the stratosphere and $10 \%$ in the troposphere. ${ }^{6}$ According to the manufacturer, the precision of the temperature of the RS80 is $0.5^{\circ} \mathrm{C}$, while humidity readings are accurate only in the lower troposphere, up to 5-8 km, but less significant above.

The ozone probe program began with bi-monthly measurements from September 1992 to December 1998, further enhanced to weekly probes in January 1999 when the station became part of the SHADOZ network. ${ }^{6}$ The objective of this network is to document the tropospheric ozone concentrations to better assess the estimation of tropical tropospheric ozone budget and to participate in satellite validation. To fulfill these objectives, an ozone probe is launched every week from 12 stations of the southern subtropics. Within this framework, the Reunion Island ozone probe system was involved in the JOSIE 2000 project, where the ECC probes and the methods of preparation used at SHADOZ sites were tested and qualified. $^{7}$

In addition to the routine program, some radiosounding specific campaigns are organized, for studying mesoscale dynamical events in the troposphere and stratosphere-troposphere exchange induced by the subtropical jet stream (15 additional soundings in July 1998), ${ }^{8}$ or by the tropical convection (8 additional soundings in February 2002) or for validating remote sensing measurements from long duration balloons passing close to the station (2 soundings in February 2001 and 2 in February 2004). ${ }^{9}$

In order to assess the water vapor distribution in the tropical UTLS and in the framework of the validation of satellites AQUA and AURA, some specific radiosoundings have been performed using a dedicated sensor developed by NOAA at the University of Colorado ${ }^{10}$ allowing water vapor measurements in the local UTLS. Two specific campaigns were performed in March 2004 and February 2005.

\section{SAOZ UV-visible spectrometer}

The SAOZ (Système d'Analyse par Observation Zénitale) is an automated UV-visible spectrometer developed by the Service d'Aéronomie at the end of the eighties for studying the polar stratosphere. ${ }^{11}$ It is a UV-visible spectrometer of $1 \mathrm{~nm}$ resolution looking at the sunlight scattered at zenith in the $300-$ $630 \mathrm{~nm}$ spectral range. The spectrometer, housed in a waterproof container with a quartz window to enable measurements at zenith within a $10^{\circ}$ conical field of view, is installed on the roof of the laboratory building. Total ozone and $\mathrm{NO}_{2}$ columns are measured twice a day at sunrise and sunset between $86^{\circ}-91^{\circ}$ solar zenith angle with an accuracy of, respectively, 3 and $5 \%$.

The first SAOZ equipped with a 512 pixel detector was installed at Reunion Island in 1993. The detector was replaced by one with 1024 pixels in 1997 after a detector failure. The SAOZ instrument has been further updated from the HewlettPackard to a PC version in 2002. Between 250 and 350 days of measurements are available every year archived in the NDSC database.

Fig. 5 shows the series of data retrieved since 1993. Both ozone and $\mathrm{NO}_{2}$ show a seasonal cycle of, respectively $24 \mathrm{DU}$ (Dobson units) and $1.17 \times 10^{15} \mathrm{~mol} \mathrm{~cm}^{-2}$ average amplitude, 

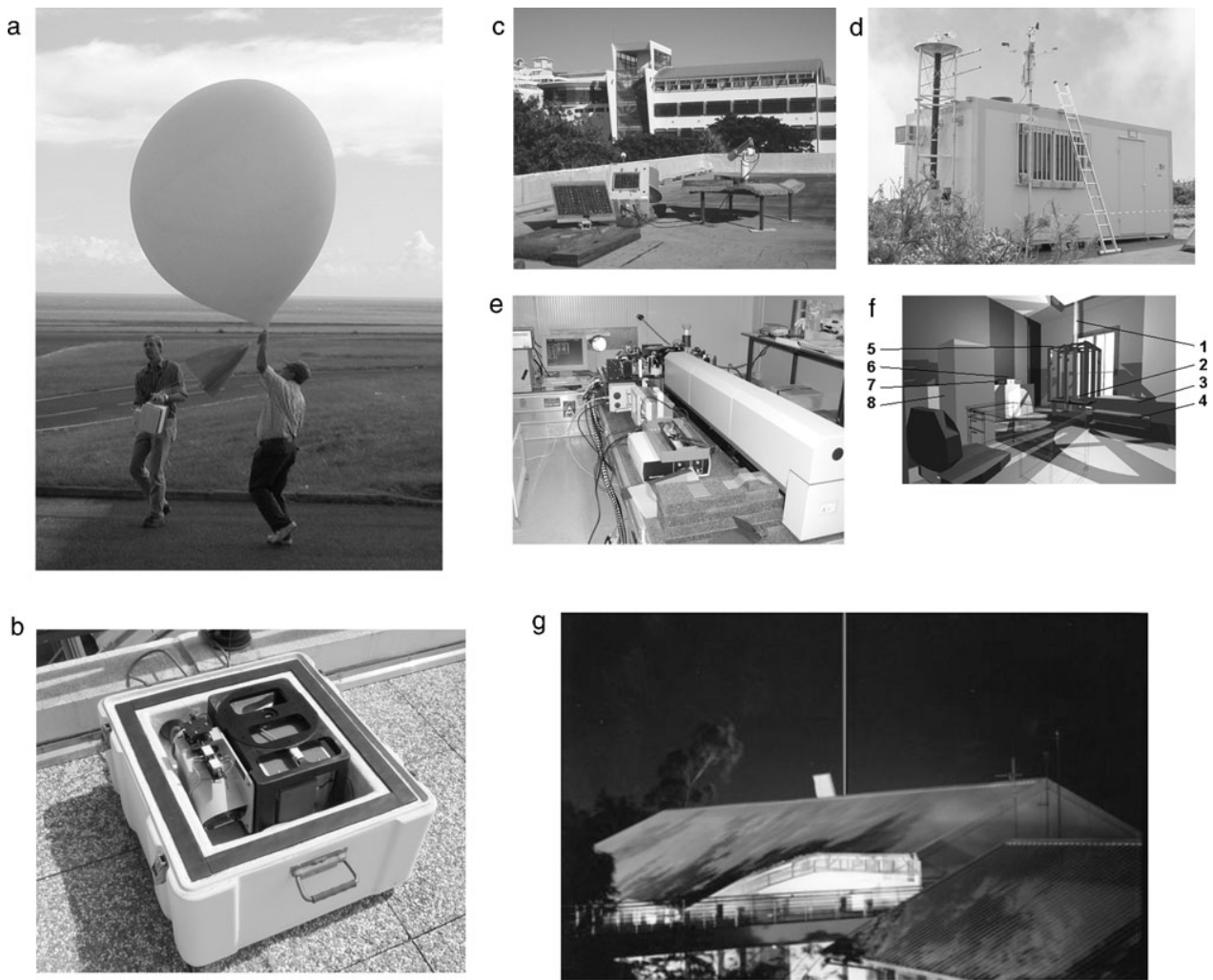

Fig. 4 Photos of the instruments: (a) ozone probe; (b) SAOZ; (c) Sun-photometer; (d) FTIR container at Piton Maïdo; (e) FTIR instrument at the university; (f) image of the stratospheric ozone LiDAR with the different component labelled (1: laser beam, 2: parabolic mirrors, 3: excimer laser, 4: Nd:YAG laser, 5: optical fibers, 6: spectrometer bloc and photomultiplier tubes, 7: mechanical chopper, 8: electronic chain); (g) laser beam emitted by the Rayleigh-Mie-Raman LiDAR.

with a late autumn-winter minimum and a spring maximum. Additional noise can be seen on $\mathrm{NO}_{2}$ : it is due to urban pollution since the instrument is located in the city of Saint Denis. A multi-regression analysis has been performed on these data showing a significant quasi-biennial oscillation modulation of 17 DU for ozone as well as some influence of magnetic activity of $8 \mathrm{DU}$, while the largest modulation on $\mathrm{NO}_{2}$ after the seasonal cycle is the ENSO with an average reduction of $0.45 \times 10^{15} \mathrm{~mol} \mathrm{~cm}^{-2}$ during the El Nino event of

Table 1 Number of times each routine instrument was operated per year

\begin{tabular}{llllll}
\hline & $\begin{array}{l}\text { T-aerosol } \\
\text { LiDAR }\end{array}$ & $\begin{array}{l}\text { Strato-O }_{3} \\
\text { DIAL }^{a}\end{array}$ & $\begin{array}{l}\text { Tropo-O }_{3} \\
\text { DIAL }^{a}\end{array}$ & SAOZ & $\begin{array}{l}\mathrm{O}_{3} \\
\text { probes }\end{array}$ \\
\hline 1992 & & & & & 13 \\
1993 & & & & 94 & 22 \\
1994 & 54 & & & 341 & 16 \\
1995 & 90 & & 321 & 18 \\
1996 & 130 & & & 181 & 17 \\
1997 & 102 & & 36 & 116 & 25 \\
1998 & 54 & & 32 & 304 & 35 \\
1999 & 99 & 28 & 17 & 314 & 49 \\
2000 & 83 & 8 & 4 & 217 & 28 \\
2001 & 59 & 8 & 30 & 111 & 30 \\
2002 & 88 & 8 & 24 & 326 & 21 \\
2003 & 93 & 0 & 52 & 255 & 41 \\
2004 & 115 & 14 & 61 & 261 & 43 \\
2005 & 121 & 10 & & &
\end{tabular}

${ }^{a}$ DIAL $=$ DIfferential Absorption Lidar.
1998-99. After removing those contributions no significant trend could be observed since 1993. Together with those of the other SAOZ stations, the Reunion Island data are being extensively used for the validation of TOMS, GOME and more recently SCIAMACHY and OMI ozone and $\mathrm{NO}_{2}$ space instruments, for which very limited observations from the southern tropics are available. ${ }^{12}$

\section{MAXDOAS UV-visible spectrometer}

The Multi-AXis DOAS (MAXDOAS) instrument is another UV-visible spectrometer designed to measure stratospheric and/or tropospheric columns of a variety of atmospheric trace

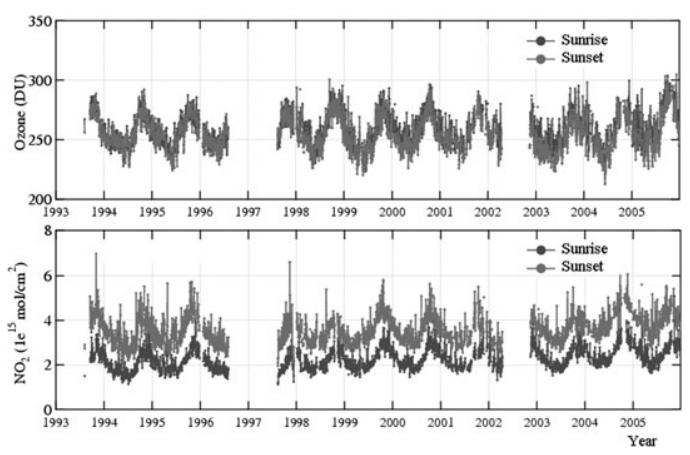

Fig. 5 Ozone (top) and nitrogen dioxide total columns obtained from 1993 to 2005 by the SAOZ spectrometer installed at Reunion Island. 
gases $\left(\mathrm{NO}_{2}, \mathrm{BrO}, \mathrm{HCHO}, \mathrm{O}_{3}, \mathrm{SO}_{2}, \mathrm{IO}, \mathrm{O}_{4}\right) .{ }^{13}$ Assembled at BIRA-IASB (Institut d'Aéronomie Spatiale de Belgique), the instrument has been installed at the University of Saint-Denis in July 2004 during the second campaign of the FTIR instrument (described in the following section), and after that continuously operated during one full year except for the period from March 25 until April 28, 2005, when it had to been dismantled due to a storm. Longer-term operation is foreseen from 2007 onwards.

In its current configuration, the MAXDOAS instrument consists of a grating spectrometer from ARC (Acton Research Corporation SpectraPro 275) equipped with a grating of 600 grooves $\mathrm{mm}^{-1}$ that covers the spectral range from 300 to $450 \mathrm{~nm}$ with a resolution of approximately $0.75 \mathrm{~nm}$ FWHM. The detector is a two-dimensional back-illuminated CCD array from Roper Scientific (NTE/CCD-400EB) operated at the nominal temperature of $-40{ }^{\circ} \mathrm{C}$. A fiber optic bundle mounted on a telescope and coupled to a rotating mirror is used to collect the skylight scattered from a series of elevation angles (typically $3^{\circ}, 6^{\circ}, 10^{\circ}, 18^{\circ}$ and zenith) within a field of view of approximately one degree. The whole system is placed inside a thermally regulated container that is directed towards the north. The data acquisition is controlled automatically via a computer and an internet connection allows for remote processing of the recorded spectra.

The MAXDOAS observations are intended to be complementary to the SAOZ total ozone and $\mathrm{NO}_{2}$ measurements already conducted on the site since 1993 by allowing the detection of more trace gases as well as enabling a more accurate separation of their tropospheric and stratospheric contents. In the current stage of the data evaluation, the capability of the system to detect spectral absorption features of all primary target gases $\left(\mathrm{NO}_{2}, \mathrm{O}_{3}, \mathrm{HCHO}, \mathrm{SO}_{2}\right.$ and $\left.\mathrm{BrO}\right)$ has been demonstrated. More specifically the analysis of $\mathrm{BrO}$ data has received a special attention. A new retrieval scheme has been designed to infer the tropospheric and stratospheric $\mathrm{BrO}$ columns based on an analysis of the complete diurnal evolution of the measured column. The evaluation makes uses of a multiple-scattering radiative transfer code coupled to a chemical box model that properly accounts for the large gradients in the stratospheric BrO field at twilight. ${ }^{12}$ Results confirm the presence of a free-tropospheric $\mathrm{BrO}$ background of approximately $1 \times 10^{13} \mathrm{~mol} \mathrm{~cm}^{-2}$ corresponding to approximately $1-2$ pptv at $6 \mathrm{~km}$ altitude. The inferred total columns are consistent with simultaneous observations from the SCIAMACHY instrument on board ENVISAT.

\section{FTIR spectrometer}

The FTIR (Fourier transform infra-red) instrument is a high spectral resolution Fourier transform spectrometer able to provide quasi simultaneously total column and/or vertical profiles of about 20 atmospheric species among which are ozone, $\mathrm{CO}, \mathrm{N}_{2} \mathrm{O}$, OCS, $\mathrm{HF}, \mathrm{HCl}$ and $\mathrm{HNO}_{3}$.

Up to now, FTIR solar absorption measurements have been made using commercially available Bruker $120 \mathrm{M}$ spectrometers. The observations are not running in routine mode but are performed on a campaign basis in the framework of a collaboration between the Université de la Réunion and the
Belgian institutes, ULB (Université Libre de Bruxelles) and BIRA-IASB. Two FTIR measurement campaigns have been performed. A first campaign was organized in SeptemberOctober 2002 during which measurements have been performed from two sites at very different altitudes (Universityof Saint Denis, $50 \mathrm{~m}$ asl and Piton Maïdo, $2200 \mathrm{~m}$ asl, Fig. 3b). The data obtained at Piton Maïdo at $2200 \mathrm{~m}$ were of very good quality. At the sea level site (University of Saint Denis), because of too high $\mathrm{H}_{2} \mathrm{O}$ vapor absorptions, a few species could not be observed, like NO, or showed larger uncertainties, like is the case for HF. But the overall quality of the data was good and reliable data retrievals could be performed. For logistical reasons, the second campaign (July to end of October 2004) took place at the university site. These campaigns have demonstrated the feasibility of a long-term monitoring of the atmospheric composition based on FTIR solar absorption observations, especially if they are performed at a high altitude station.

During these campaigns, the following observations have been made. In 2002, the differential column of tropospheric species such as $\mathrm{N}_{2} \mathrm{O}$ and $\mathrm{C}_{2} \mathrm{H}_{2}$ in the $2150 \mathrm{~m}$ thick layer between the altitudes of both observation sites has been observed. In 2004, the seasonal variation of CO in the local spring period has been in good agreement with correlative MOPITT data. The comparisons between the FTIR retrieved profiles for $\mathrm{HNO}_{3}$ and $\mathrm{O}_{3}$ and overpass data of the ACE/ SciSat-1 satellite instrument and local $\mathrm{O}_{3}$ probe measurements showed a good agreement confirming the reliability of the FTIR data.

Further data analysis of the 2004 campaign is still ongoing. Among others, we are investigating the information content of the FTIR spectra regarding water vapor in the upper troposphere/lower stratosphere. The FTIR experiment has been run using BARCOS, the Bruker Automation and Remote Control System, developed at IASB-BIRA for enabling the operation of the FTIR instrument in an automatic or remotely-controlled way. ${ }^{14,15} \mathrm{We}$ intend to use this system in any future campaign as well as for the permanent operations in the future NDACC infrastructure.

\section{Sun-photometer}

A CE 318 automatic sun tracking photometer designed and realized by CIMEL has been installed in 1997, in collaboration with the LOA (Laboratoire d'Optique Atmosphérique) and NASA. This instrument is the standard instrument used in the AERONET (AErosol RObotic NETwork) international network which provides most of aerosol optical measurements used to characterize the aerosol properties and to validate satellite data. ${ }^{16}$ The CIMEL 318 measures the solar radiance in 6 spectral bands: 440, 670, 870, 936, and $1020 \mathrm{~nm}$. The spectral band of $870 \mathrm{~nm}$ is measured from 3 polarized channels of 120 degrees. This instrument gives the integrated optical thickness of atmospheric aerosols, the volume size distribution, and the Angström coefficient.

Two measurement campaigns have first been organized: the first one was performed at Pas de Bellecombe (June 1997-June 1998), near the volcano Piton de la Fournaise, while the second campaign (March 1999-May 2000) took place at 
St Pierre, in the south west of Reunion Island (Fig. 3b). The instrument works again routinely since January 2004 at the University (Saint Denis). In addition, a second instrument (type CE 312) has been installed since January 2006 in order to provide measurements in the infra-red spectral band simultaneously with LiDAR measurements of clouds and aerosols. Data are treated by PHOTONS-AERONET and are available on internet (web links in appendix).

\section{LiDAR measurements}

The principle of the LiDAR is based on the active emission of laser pulses in the atmosphere. ${ }^{17}$ Backscattered photons by atmospheric layers result from an elastic or inelastic diffusion. Depending on the emission/detection characteristics, the return signals are processed in order to derive accordingly, on a daily basis, atmospheric parameters. Two LiDAR systems are operating, one for aerosol, temperature, water vapor and tropospheric ozone profiles, and a second for stratospheric ozone profiles.

\section{Temperature and aerosol profiles}

The first LiDAR operating at Reunion observatory was a Rayleigh-Mie one. It has been devoted to retrieve temperature and aerosol profiles by the use of two channels in the 30-75 km and $12-35 \mathrm{~km}$ height ranges, respectively. The initial laser was a Nd:YAG laser, doubled by a KDP crystal, in order to emit at $532 \mathrm{~nm}$, with a repetition rate of 10 pulses per second, and delivering $300 \mathrm{~mJ}$ per pulse. In 1996, the laser source was changed. The operating laser is a Nd:YAG emitting with a higher repetition rate $(30 \mathrm{~Hz})$ and delivering $500 \mathrm{~mJ}$ pulse ${ }^{-1}$. The reception system is composed by a mosaic of 4 parabolic mirrors, with a diameter of $500 \mathrm{~mm}$ each; the backscattered signal is transmitted using optical fibers to photomultiplier tubes (Hamamatsu R1477S). The electronic chain is similar to that operating at the Observatoire de Haute Provence in the South of France. ${ }^{18,19}$

Due to the aerosol distribution, temperature retrieval from a Rayleigh-Mie LiDAR is possible only for altitudes higher than $30 \mathrm{~km}$ (where aerosol contribution to the LiDAR signals is negligible). In order to extend temperature measurements by the LiDAR downward, a Raman- $\mathrm{N}_{2}$ setup has been implemented in $1999 .{ }^{20}$ The Raman- $\mathrm{N}_{2}$ method is based on the Raman shift induced by the nitrogen molecules.

\section{Clouds, aerosol and water vapor profiles}

Aerosol profiles obtained from the Rayleigh-Mie channels do not cover all tropospheric heights. Those channels are also dedicated to detect and characterize the seasonal and vertical distribution of the tropical cirrus clouds over the Reunion site. In November 1995, the LiDAR was improved by adding new channels using a smaller telescope (diameter $200 \mathrm{~mm}$ ), to extend the aerosol altitude range downwards. The installation of a dioptric afocal optical system allows the reduction of the emitted laser beam divergence. Polarized channels have also been implemented, especially to study cirrus clouds. In 1997, six simultaneous counting channels were installed, using the infra-red fundamental Nd:YAG emission. Raman channels allow to retrieve tropospheric temperature ${ }^{20}$ and water vapor concentration. ${ }^{21}$ The technology used is presented by Whiteman et $a .^{22}$ The detection of Raman signals is obtained by a Czerny-Turner spectrometer using a holographic grating. The water vapor mixing ratio is deduced from the ratio between the shifted Raman backscattered photons and the Raman nitrogen backscattered photons. This second signal is used as a reference and allows to derive directly the water vapor mixing ratio with a limited sensitivity to instrumental parameters. However, modifications of the filtering devices and detectors are specific to each channel. Today some calibrations of water vapor measurements remain to be realized and hence this channel is still in a validation phase.

\section{Tropospheric ozone profiles}

In 1998, a differential LiDAR system has been implemented in order to measure tropospheric ozone. The method is based on the differential absorption between two UV wavelengths $(289 \mathrm{~nm}$ and $316 \mathrm{~nm})$, generated in a high pressure deuterium cell. Because of difference in beam emission divergence (between visible and UV beams) and in expected vertical ranges (troposphere for ozone, stratosphere for temperature), the use of the fibers of the temperature-aerosol system was not appropriate and an original system of double fibers has been developed, constituting the originality of this system. ${ }^{23}$ The spectral separation of both wavelength of the ozone system is obtained by a Czerny-Turner spectrometer using a holographic grating. The reception system is common with the temperature Rayleigh/Raman system.

\section{Stratospheric ozone profiles}

Another LiDAR system, built by Geneva University (Switzerland) in collaboration with the Service d'Aéronomie has been implemented at Reunion Island in June 2000. The principle is the same as for the LiDAR used for tropospheric ozone measurements. However, to observe the stratosphere, it is necessary to use wavelengths less absorbed by ozone and the emitted wavelengths are shifted towards the near UV. ${ }^{24}$ Thus, the technical choices for the beam generation are different: two lasers are used, one Nd:YAG tripled producing the $355 \mathrm{~nm}$ wavelength at $30 \mathrm{~Hz}$ and $150 \mathrm{~mJ}$ per pulse and one Excimer laser producing the $308 \mathrm{~nm}$ wavelength at $40 \mathrm{~Hz}$ and $200 \mathrm{~mJ}$ per pulse.

The reception system is similar to the other LiDAR system (same mosaic of 4 parabolic mirrors and transmission of signal by optical fibers). To avoid the saturation of the photomultiplier tubes, a mechanical chopper rotating in vacuum at $800 \mathrm{~Hz}$ is used. A separation lens after the spectrometer block is also used to separate the return signal in two channels in the proportions of $8 \%$ for the lower stratospheric channel and of $92 \%$ for the upper stratospheric channel. In addition, electronic gating is used for upper stratospheric channels.

With a time integration of two hours, the statistical error linked to the signal ãN noise ratio is less than $10 \%$ between 18 and $38 \mathrm{~km}$, and less than $5 \%$ between 20 and $35 \mathrm{~km}$. This instrument is well adapted to the survey of stratospheric ozone over Reunion Island. On 20 July 2000, both tropospheric and stratospheric ozone DIAL systems operated simultaneously, and an ozone probe was launched. As depicted on Fig. 6, 


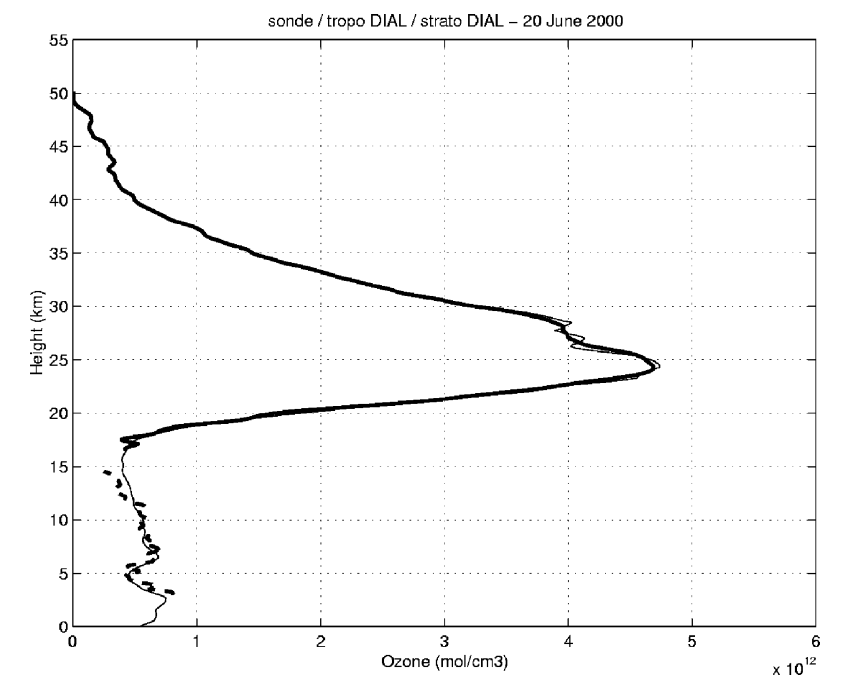

Fig. 6 Ozone profiles by stratospheric DIAL (bold), tropospheric DIAL (dotted) and ozone probe (thin) on 20 June 2000.

corresponding ozone profiles show a good agreement. When the conditions of observations are good, ozone measurements combining the tropospheric and stratospheric systems are available from 3 to $45 \mathrm{~km}$.

\section{Scientific studies}

Some examples of scientific studies at Reunion Island are now given, to illustrate how continuous data can be used to improve our knowledge of atmospheric processes.

\section{Aerosols and tropospheric ozone balance}

Measurements provided by ozone soundings have allowed the characterization of the seasonal variability of tropospheric ozone. It has been shown that this variability results from the coupling between photochemical and dynamical processes: ${ }^{25}$ the photochemical influence of biomass burning from South Africa and Madagascar, ${ }^{26,27}$ the ozone diurnal cycle in the boundary layer $^{28}$ and the ozone loss due to cirrus clouds. $^{29,30}$ Moreover, at the end of the biomass burning season, the daily variability of the dynamical context can induce an important daily variability of the tropospheric ozone profile. $^{31}$

\section{Troposphere-stratosphere transport, dynamics of tropical cyclones}

The exchanges between stratosphere and troposphere have been especially examined and the relative roles of processes like tropopause fold, ${ }^{8}$ Rossby wave breaking and tropical cutoff lows ${ }^{32}$ or tropical convection ${ }^{33}$ have been quantified. The localization of Reunion Island makes it ideal for the observation of cyclones during the austral summer. Therefore tropical cyclones have been the subject of many studies such as Doppler radar observations of tropical cyclone Dina, ${ }^{34}$ mesoscale modelisation of gravity waves generated by cyclone Hudah, ${ }^{35}$ and of stratosphere-troposphere exchange generated by cyclone Marlene ${ }^{36}$ or the effects of Rossby wave breaking on cyclogenesis, intensity and trajectories of cyclones.

Presently, we are working mainly on the use of dynamical tools such as Reverse Domain Filling techniques, Flexpart and mesoscale models (meso-nh and MM5) to obtain more insight to these processes.

\section{Atmospheric dynamics}

It is well established that the subtropical barrier, a dynamical border that separates the tropical stratospheric reservoir from mid-latitudes, as for the polar vortex, controls and limits the meridional exchanges. Indeed, the efficiency of the confinement of the tropical stratospheric reservoir depends on the strength of the subtropical barriers and on their variability. ${ }^{37}$ Recent studies conducted at Reunion University, combining ground-based and satellite measurements together with global modeling, showed that developments of laminae nearby the southern subtropical barrier might be associated with the anomalous growth and break of gravity waves and planetary waves that propagate from the troposphere into the stratosphere during winter. ${ }^{38,39}$ In fact, with regard to its geographical position in the southern tropics, the Reunion site might be under influences of several transient and/or seasonal dynamical processes, such as ITCZ, convective and cyclone developments, jet-streams, or subtropical barriers.

Up to now, the number of ground-based instruments running in the Tropics has still been limited. We thus have taken the advantage of the variety of qualified atmospheric datasets offered at Reunion Island, to contribute to several topics related to dynamical processes in the stratosphere-upper troposphere region:

(1) Atmospheric tides and gravity waves characteristics by the use of daily LiDAR temperature profiles; ${ }^{40-42}$

(2) Survey and variability of isentropic transport and planetary waves propagation nearby the southern subtropical barrier, by the use of ozone profiles obtained by LiDAR and radio probes and daily ozone columns recorded by SAOZ $;^{37}$

(3) Stratospheric ozone trend estimation using satellite (SAGE II, HALOE) and radio probe data;

(4) Tropical tropopause characteristics; ${ }^{43}$

(5) Climatology and variability of stratospheric parameters: temperature, ozone and aerosols. ${ }^{18,20,44}$

In fact the LiDAR technique, as well as radiosounding, are well adapted to study the dynamic and variability of the stratosphere-upper troposphere region at different timescales, through regular measurements of atmospheric key parameters: temperature, ozone, water vapour, and aerosol contents.

\section{Conclusion and future plans}

In order to provide significant improvement of our understanding of the dynamic of the tropical troposphere and stratosphere, scientific studies have to be based on the complementarity of several different instruments, and of multiple approaches (ground based observations, satellite data, and models). These studies contribute to the support of the decisions taken in international agreements like the Montreal protocol, relative to the production of CFCs and halogenated 
species, or like the Kyoto protocol, relative to emissions of greenhouse gases.

The atmospheric survey is, then, important all over the globe, and especially in the tropical region, which is a key region for many mechanisms playing a role in climate change. Reunion Island is an exceptional site for the study of atmospheric dynamics, and participates in this international effort. The instrumentation of this station uses recent technologies, and studies based on the recorded data are of a special interest for understanding processes, climatologies and trends.

However, measurement techniques are still lacking, especially for dynamical observations and the measurement of water vapor in the UTLS is an actual instrumental challenge. Then, in the near future, in order to improve the contribution of Reunion Island in this regard, some additional instruments will be implemented:

-A Doppler LiDAR giving horizontal components of the wind from 5 to $50 \mathrm{~km}$, for the study of gravity wave activity. ${ }^{45}$

A micro-wave radiometer with one large $(8-13 \mathrm{~m})$ and three thick $(8.2-9.2 \mathrm{~m} / 10.3-11.3 \mathrm{~m} / 11.5-12.5 \mathrm{~m})$ spectral bands in the infrared in order to assess the tropical cirrus cloud microphysics, such as the size of the crystals.

A radiometer giving the water vapor profile from 15 to $60 \mathrm{~km}$, with a vertical resolution of $5-15 \mathrm{~km}$, for the survey of the tropical UTLS variability.

The last plan for the future of this site is to build an altitude station at Piton Maïdo, located in the western part of the island, $2200 \mathrm{~m}$ asl (Fig. 3b). The building of the altitude station is expected by 2010. The functioning of many instruments (LiDAR, FTIR and radiometers especially) will be improved, avoiding the perturbation by the humidity contained in the lower layer of the tropical troposphere. This new altitude station will be a platform to receive other instruments on a temporary basis for international campaigns. Moreover, in the future, the station could be included in the OARA structure (Observatoire Atmosphérique des terres australes) grouping the activities of all the southern hemisphere French atmospheric stations (Reunion, Crozet, Saint Paul, Kerguelen and Amsterdam islands) and new instrumentation onboard the research vessel Marion Dufresne.

\section{Appendix}

\section{Web links of data networks}

AERONET, http://aeronet.gsfc.nasa.gov/; PHOTONS, http:// www-loa.univ-lille1.fr/photons/; NDSC (NDACC), http:// www.ndsc.ws/; SHADOZ, http://croc.gsfc.nasa.gov/shadoz/.

\section{Acknowledgements}

Gérard Mégie (1946-2004) was an internationally recognized scientist and played a leading role in setting up the Network for the Detection of Stratospheric Changes. The development of an atmospheric station at Reunion Island has been made possible thanks to his action at the Service d'Aéronomie, then at CNRS. We acknowledge the work of the technical staff of Reunion Island and of the collaborating laboratories, with a special attention to Guy Bain and Stéphane Richard. The
MAXDOAS and FTIR campaigns (IASB-BIRA and ULB) are funded by the Belgian Science Policy through the IASI and ACE ESA-Prodex arrangements and the national project ESACII. The station is supported by French regional, national (PNCA, INSU, CNRS), and international (EQUAL, NASA/ GFSC) fundings.

\section{References}

1 WMO, Scientific assessment of ozone depletion: 1991 (WMO Global ozone research and monitoring project, report no 25), World Meteorological Organization, Geneva, 1991.

2 IPCC, Climate change: the IPCC scientific assessment, Cambridge University Press, Cambridge, UK, 1990.

3 D. J. Wuebbles, A. Jain, J. Edmonds, D. Harvey and K. Hayhoe, Global change: state of the science, Environ. Pollut., 1999, 100, 57-86.

4 M. J. Kurylo and S. Solomon, Network for the Detection of Stratospheric Change: a status and implementation report, NASA Upper Atmosphere Research Program and NOAA Climate and Global Change Program (NASA), NASA, Washington, DC, 1990.

5 J. F. Royer, D. Cariolle, F. Chauvin, M. Déqué, H. Douville, R. M. Hu, S. Planton, A. Rascol, J. L. Ricard, D. Salas, Y. Melia, F. Sevault, P. Simon, S. Somot, S. Tyteca, L. Terray and S. Valcke, Simulation des changements climatiques au cours du XXI ${ }^{\text {ème }}$ siècle incluant l'ozone stratosphérique, C. R. Geosci., 2002, 334, 147-154.

6 A. M. Thompson et al., The 1998-2000 SHADOZ (Southern Hemisphere ADditional OZonesondes) tropical ozone climatology. 1. Comparisons with TOMS and ground-based measurements, J. Geophys. Res., 2003, 108, 8238.

7 H. G. J. Smit, W. Straeter, B. Johnson, S. Oltmans, J. Davies, D. W. Tarasick, B. Hoegger, R. Stubi, F. Schmidlin, T. Northam, A. Thompson, J. Witte, I. Boyd and F. Posny, Assessment of the performance of ECC-ozonesondes under quasi-flight conditions in the environmental simulation chamber: Insights from the Jülich Ozone Sonde Intercomparison Experiment (JOSIE), J. Geophys. Res., 2006, submitted.

8 J. L. Baray, V. Daniel, G. Ancellet and B. Legras, Planetary-scale tropopause folds in the southern subtropics, Geophys. Res. Lett., 2000, 27(3), 353-356.

9 F. Borchi, J. P. Pommereau, A. Garnier and M. Pinharanda, Evaluation of SHADOZ sondes, HALOE and SAGE II ozone profiles at the tropics from SAOZ UV-Vis remote measurements onboard long duration balloons, Atm. Chem. Phys., 2005, 5, 1381-1397.

10 H. Vömel, S. J. Oltmans, D. J. Hofmann, T. Deshler and J. M. Rosen, The evolution of the dehydration in the Antarctic stratospheric vortex, J. Geophys. Res., 1995, 100(13), 919-13-926.

11 J. P. Pommereau and F. Goutail, $\mathrm{O}_{3}$ and $\mathrm{NO}_{2}$ ground-based measurements by visible spectrometry during Arctic winter and spring 1988, Geophys. Res. Lett., 1988, 15, 891-894.

12 J. C. Lambert et al., Combined characterisation of GOME and TOMS total ozone measurements from space using ground-based observations from the NDSC, Adv. Space Res., 2000, 26, 1931-1940.

13 N. Theys et al., Determination of tropical stratospheric and tropospheric $\mathrm{BrO}$ columns from multi-axis DOAS measurements at Reunion Island, Atmos. Chem. Phys. Discuss., 2006, paper in preparation.

14 E. Neefs et al., The BARCOS system for automatic and remote control of a Bruker FTS for solar absorption measurements from ground, OSA, Quebec, 2003.

15 E. Neefs et al., BARCOS: a system for making atmospheric observations with a Bruker FTS in an automatic or remotely controlled way, Rev. Sci. Instrum., 2006, submitted.

16 B. N. Holben, T. F. Eck, I. Slutsker, D. Tanre, J. P. Buis, A. Setzer, E. Vermote, J. A. Reagan, Y. Kaufman, T. Nakajima, F. Lavenu, I. Jankowiak and A. Smirnov, AERONET - A federated instrument network and data archive for aerosol characterization, Remote Sens. Environ., 1998, 66, 1-16.

17 A. Hauchecorne and M. L. Chanin, Density and temperature profiles obtained by lidar between 35 and 70 km, Geophys. Res. Lett., 1980, 565-568. 
18 H. Bencherif, J. Leveau, J. Porteneuve, P. Keckhut, A. Hauchecorne, G. Mégie, F. Fassina and M. Bessafi, LiDAR Developments and Observations over Reunion Island $\left(20.8^{\circ} S, 55.5^{\circ} \mathrm{E}\right)$, proceedings of the 18th International Laser Radar Conference, ed. A. Ansmann, R. Neuber, P Rairoux and U. Wandinger, Springer Verlag, Berlin, 1996, pp. 553-556.

19 A. Hauchecorne, M. L. Chanin, P. Keckhut and D. Nedeljkovic, LiDAR monitoring of the temperature in the middle and lower atmosphere, Appl. Phys. B, 1992, 55, 29-34.

20 D. Faduilhe, P. Keckhut, H. Bencherif, L. Robert and S. Baldy, Stratospheric temperature monitoring using a vibrational Raman LiDAR. Part 1: Aerosols and ozone interferences, J. Environ. Monit., 2005, 7, 357-364.

21 L. Robert, P. Keckhut, L. Leveau, F. Chane-Ming and J. Porteneuve, Development of Raman water-vapor LiDAR at a NDSC complementary station in the southern tropics, Proceedings of ILRC 22, Matera, Italy, 12th-16th July 2004, 2004, vol. 1, pp. $111-114$.

22 D. Whiteman, et al., Raman LiDAR system for the measurement of water vapour and aerosols in the earth atmosphere, Appl. Opt., 1992, 3, 3068-3082.

23 J. L. Baray, J. Leveau, J. Porteneuve, G. Ancellet, P. Keckhut, F. Posny and S. Baldy, Description and evaluation of a tropospheric ozone lidar implemented on an existing lidar in the southern subtropics, Appl. Opt., 1999, 38, 6808-6817.

24 S. Godin-Beekmann, J. Porteneuve and A. Garnier, Systematic DIAL ozone measurements at Observatoire de Haute-Provence, $J$. Environ. Monit., 2003, 5, 57-67.

25 S. Baldy, G. Ancellet, M. Bessafi, A. Badr and D. Lan-Sun-Luk, Field observations of the vertical distribution of tropospheric ozone at the Island of La Reunion, J. Geophys. Res., 1996, 101, 23835-23849.

26 T. Randriambelo, S. Baldy, M. Bessafi, M. Petit and M. Despinoy, An improved detection and characterization of active fires and smoke plumes in Southeastern Africa and Madagascar, Int. J. Remote Sens., 1998, 19, 2623-2638.

27 F. G. Taupin, M. Beekmann, P. J. Bremaud and T. Randriambelo, Ozone generation over the Indian Ocean during the South African biomass-burning period: case study of October 1992, Ann. Geophys., 2001, 19, 1-11.

28 P. J. Bremaud, F. Taupin, A. M. Thompson and N. Chaumerliac, Ozone nighttime recovery in the marine boundary layer: Measurement and simulation of the ozone diurnal cycle at Reunion Island, J. Geophys. Res., 1998, 103, 3463-3473.

29 S. Roumeau, P. Bremaud, E. Riviere, S. Baldy and J. L. Baray, Tropical cirrus clouds: a possible sink for ozone, Geophys. Res. Lett., 2000, 27, 2233-2236.

30 B. Cadet, L. Goldfarb, D. Faduilhe, S. Baldy, V. Giraud, P. Keckhut and A. Rechou, A sub-tropical cirrus clouds climatology from Reunion Island $\left(21^{\circ} \mathrm{S}, 55^{\circ} \mathrm{E}\right)$ lidar data set, Geophys. Res. Lett., 2003, 30, 1130-1133.

31 T. Randriambelo, J. L. Baray, S. Baldy, A. M. Thompson, S. Oltmans and P. Keckhut, Investigation of the short-time variability of tropical tropospheric ozone, Ann. Geophys., 2003, 21, 2095-2106.

32 J. L. Baray, S. Baldy, R. D. Diab and J. P. Cammas, Dynamical study of a tropical cut-off low over South Africa and its impact on tropospheric ozone, Atmos. Environ., 2003, 37, $1475-1488$.

33 J. L. Baray, G. Ancellet, T. Randriambelo and S. Baldy, Tropical cyclone Marlene and stratosphere-troposphere exchange, J. Geophys. Res., 1999, 104, 13953-13970.

34 F. Roux, F. Chane Ming and A. Lasserre-Bigorry, Doppler radar observations of tropical cyclone Dina as it passed near La Réunion on 22 January 2002, Proceedings of the Second European Conference on Radar Meteorology (ERAD), Delft, 18th-22nd November, 2002, 2002, p. 6.

35 F. Chane Ming, G. Roff, L. Robert and J. Leveau, Gravity wave characteristics over Tromelin Island during the passage of cyclone Hudah, Geophys. Res. Lett., 2002, 29, 1094.

36 J. Leclair de Bellevue, J. L. Baray, S. Baldy and G. Ancellet, Stratosphere-troposphere exchange near tropical convection: observations, mesoscale and global analyses, SPARC $3 \mathrm{rd}$ General Assembly, Victoria, BC, Canada, 1st-6th August, 2004, 2004.

37 T. Portafaix, B. Morel, H. Bencherif, S. Godin-Beekmann, S. Baldy and A. Hauchecorne, Fine scale study of a thick stratospheric ozone lamina at the edge of the southern subtropical barrier, J. Geophys. Res., 2003, 108, 4196-4205.

38 H. Bencherif, T. Portafaix, J. L. Baray, B. Morel, S. Baldy, J. Leveau, A. Hauchecorne, P. Keckhut, A. Moorgawa, M. Michaelis and R. Diab, Lidar observations of lower stratospheric aerosols over South Africa linked to large scale transport across the southern subtropical barrier, J. Atmos. Terr. Phys., 2003, 65, 707-715.

39 B. Morel, H. Bencherif, P. Keckhut, T. Portafaix, A. Hauchecorne and S. Baldy, Fine-scale study of a thick stratospheric ozone lamina at the edge of the southern subtropical barrier. Part II: Numerical simulations with coupled dynamics models, J. Geophys. Res., 2005, 110, D17101.

40 B. Morel, H. Bencherif, P. Keckhut, S. Baldy and A. Hauchecorne, Evidence of tidal perturbations in the middle atmosphere over Southern Tropics as observed by Rayleigh Lidar, J. Atmos. Terr. Phys., 2002, 64, 1979-1988.

41 B. Morel, P. Keckhut, H. Bencherif, A. Hauchecorne, G. Mégie and S. Baldy, Investigation of the tidal variations in a 3-D dynamics-chemistry-transport model of the middle atmosphere, J. Atmos. Terr. Phys., 2004, 66, 251-265.

42 F. Chane Ming, F. Molinaro, J. Leveau, P. Keckhut, A. Hauchecorne and S. Godin, Vertical short-scale structures in the upper tropospheric-lower stratospheric temperature and ozone at $\mathrm{La}$ Réunion island $\left(20.8^{\circ} \mathrm{S}, 55.3^{\circ} \mathrm{E}\right)$, J. Geophys. Res., 2000, 105, 26857-26870.

43 V. Sivakumar, J. L. Baray, S. Baldy and H. Bencherif, Tropopause characteristics over a southern sub-tropical site: Reunion Island $\left(21^{\circ} \mathrm{S}, 55^{\circ} \mathrm{E}\right)$ : using Radiosonde/Ozonesonde data, J. Geophys. Res., 2006, in press.

44 V. Sivakumar, P. B. Rao and H. Bencherif, Lidar observations of middle atmospheric gravity wave activity over a low latitude, Ann. Geophys., 2006, AG/2005160, in press.

45 Souprayen, C. A. Garnier, A. Hertzog, A. Hauchecorne and J. Porteneuve, Rayleigh-Mie Doppler wind LiDAR for atmospheric measurements. I. Instrumental setup validation and first climatological results, Appl. Opt., 1999, 3, 2410-2421. 